\title{
Solar cell production increase scenario coping with petroleum-resources drain
}

\section{石油源枯渴に対応するソーラーセルの増産シナリオ}

\author{
Haruhi to TANAHASHI and Sadao UEGUSA \\ Department of Electrical Engineering, Tokai University, 1117 Kitakaname, \\ Hiratsuka, Kanagawa, 259-1292 JAPAN \\ TEL: 81-0463-58-1211 (EXT. 4162)
}

(Received 19, November 2001 Accepted 26, July 2002)

By using energy effectively, human beings built rich material civilization. On the other hand, civilization produced the resources exhaustion problem and the environmental problem. Petroleum exhaustion in the 21st century will restrict an economic activity. In connection with it, it is thought that the energy source of supply by the solar cell etc. clean and stabilized over the future is required. In this paper, the scenario lighting of solar cell production prediction and solar cell production increase was performed. The future state was examined from them.

Keywords: Solar cell, Clean energy, Self-sufficiency of electric power

\section{INTRODUCTION}

人類は、資源、エネルギーを有効に利用し、大量生産、大 量消費によって豊かな物質文明を築き上げた。しかし、それ に伴う矛盾が資源枯渴問題、環境污染問題として顕在化し つつある。特に、化石燃料資源の枯渴問題は、21 世紀が担 うべき大問題の一つである。それに伴い、太陽電池などによ るクリーンで安定したエネルギー供給源が将来にわたつて必 要だと考えられる。本研究では、ニューラルネットを用いた太 陽電池生産予測を行った。さらに、石油枯渴問題に伴う価格 高騰を考慮して、2015 年までに全国の一戸建て全住宅に太 陽電池を設置し、電力の自給自足化を目標とした太陽電池 増産のシナリオライティングを行った。また、これら2つ結果に 基づき、太陽電池生産の現状から予測される普及の可能性 と、石油枯渴を踏まえた今後の在り方について分析した。

\section{CONSIDERATION}

A. The prediction of a solar cell production trend. 本論文では、ニューラルネットワークを利用したコンピュー タ予測法を使用した。 ${ }^{1}$ Figure1 に 1999 年までの日本国内に おける太陽電池生産量の推移 ${ }^{2}$ と、これを基にし、その後 15 年間の動向をニューラルネット予測した結果を示した。ここで は、2026 年に石油枯渴するという予測結果 ${ }^{3}$ の前提から、石 油価格高騰によるエネルギー不足を太陽電池によって回避 するため、2015 年までに石油資源の代替をすべきという前 提で予測とした。また、経済産業省の太陽電池補助金制度、 および各社の太陽電池生産への積極的投資は、今後も続く ものと仮定している。

その結果、Fig .1の予測動向からは、2015 年の時点で年

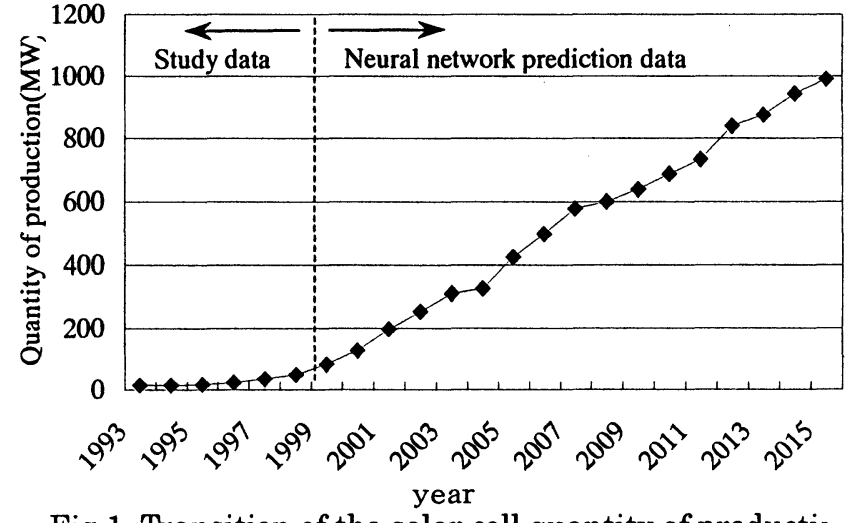

Fig.1. Transition of the solar cell quantity of production, and solar cell production prediction

間総生産量は $989 \mathrm{MW}$ の達成が予測された。また、今後の 太陽電池の生産量は、環境問題等の顕現がその設置増加 に更なる拍車をかけると考えられるが、本予測結果では、石 油資源の代替となるほどの生産量には到達しないことが明ら かである。

B. The Solar cell production increase scenario.

石油枯渴による価格高騰に対応するため、エネルギーの 自給自足を目的として、日本の一戸建て全住宅に $3 \mathrm{~kW}$ 型太 陽電池を設置すると仮定した太陽電池增産のシナリオライテ イングを行った。総務省統計局のデータに基づき全国の一 戸建て全住宅に $3 \mathrm{~kW}$ 型太陽電池を普及させるためには、総 計 76GW 以上の太陽電池が必要なことが判明している。 ${ }^{4}$

この量の太陽電池確保を目標とした 3 種類のシナリオライ テイングを作成し、それに至るまでの太陽電池増産の推移を 


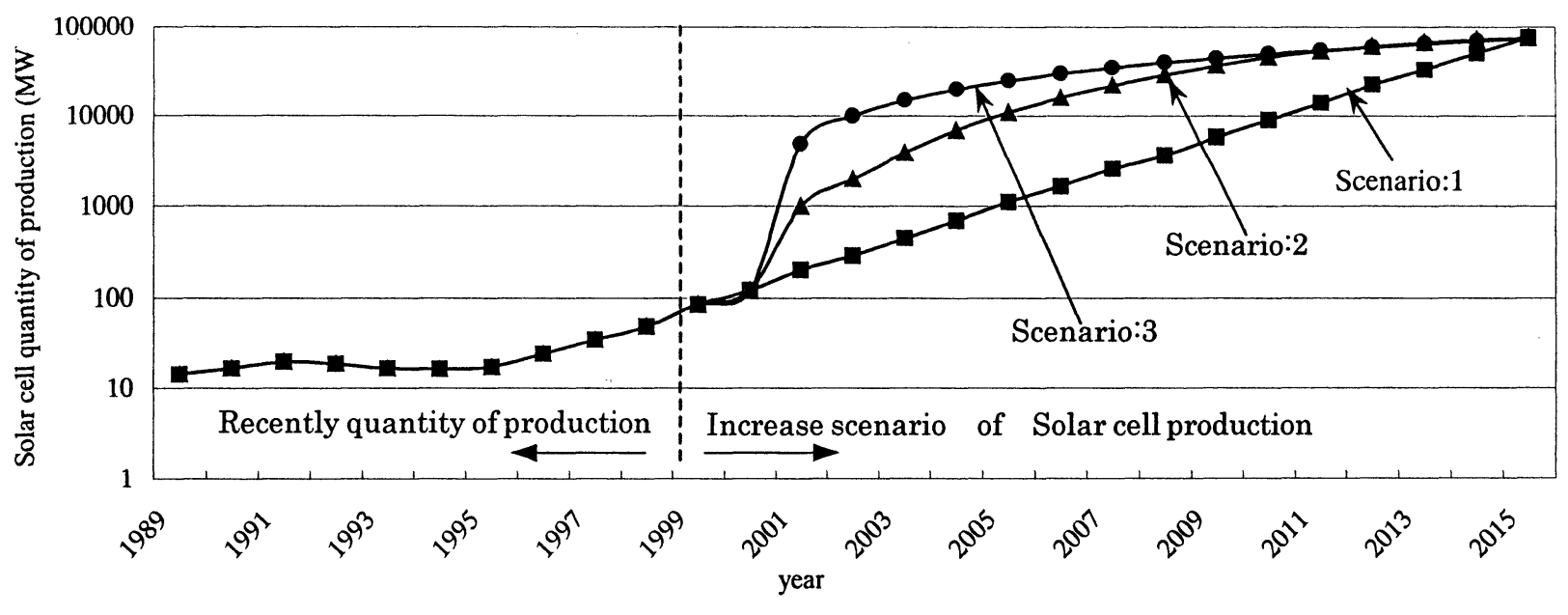

Fig.2. Solar cell production increase scenario.

Fig. 2 に示す。ただし、この数値は、あくまで一戸建て住宅を 対象にした計算值であり、マンションなどの集合住宅などは 本シナリオには加味されていない。以下に、各シナリオの仮 定を示す。

シナリオ:1

a. 増産の準備期間として、2000 年度から最初の 3 年間 はニューラルネットの予測に沿って増加させる。

b. その後、指数関数上で直線的に増加させる。

シナリオ:2

a. 初年度 (2001 年)から、1GWずつ増加量を増加させる。

b. 2010 年度でピークを迎え前年度比 $9 \mathrm{GW}$ の増加量とな る。その後、1GWずつ増加量を減少させる。

シナリオ:3

a. 毎年 $5 \mathrm{GW}$ ずつ一定に生産量を増加させる。

これらのシナリオにより、全国の一戸建て全住宅に $3 \mathrm{~kW}$ 型太陽電池を普及させることが出来れば、石油価格高騰に よるエネルギ一問題発生時において予測される社会的混乱 を緩和させることが出来ると考えられる。

また、シナリオ 3 においては、他の二つのシナリオと異なり、 その初期段階 3 年間において生産増加量を押さえることに より、将来的生産増加に向けた準備期間に当てられると考え た。しかし、他のシナリオにおいては、初期段階において準 備期間がないため、急激な増産ができず非現実的であると 考えられる。

さらに、前予測結果と本シナリオで必要としている生産量 を比較すると、約 23 万倍必要であることになる。すなわち、 現状の生産体制を改善しない限り石油価格高騰によるエネ ルギー問題の抜本的対応策にはならない。

そのため、我々の生活はもちろん、医療現場などを中心 に社会的大混乱が生ずることが予測され、これは最も避けな ければならないことである。

C. About the state of our future life style 現状から考えると、太陽電池による一般家庭での電力
の自給自足化は厳しい現状にある。しかし、石油価格高 騰によるエネルギ一問題での社会的大混乱を避けるには、 長期的見通しで太陽電池増産を積極的に行う必要がある。 また、各家庭においても太陽電池を家電並みの意識で導入 できる体制作りが、必要不可欠である。さらに、我々のライフ スタイルも根本的に見直し、無駄なエネルギー消費を避け、 物質的豊かさから精神的豊かさへと転換することを真剣に考 える必要に迫られている。2

III. CONCLUSION

（1) シナリオ 1 により、少ない負荷で太陽電池を増産させる ことができ、石油価格高騰によるエネルギー問題発生 時においても混乱を緩和させることが出来る。

(2) ニューラルネットにおける予測結果と本シナリオで必要 としている生産量を比較すると、約 23 万倍必要であるこ とになる。すなわち、現状の生産体制を改善しない限り 石油価格高騰によるエネルギ一問題の抜本的対応策 にはならない。

（3）石油価格高騰による社会的混乱を避けるためにも、長 期的見通しで太陽電池増産を行うと共に、家電並みの 意識で国民が導入できる体制作りが必要不可欠であ る。

\section{REFERENCES}

${ }^{1}$ S.Ariizumi,K.Takita,S.Uegusa; The Prediction method by neural network and the estimation method by fractal dimension 1999.

2 New Energy and Industrial Technology Development Organization; The present condition of a solar cell market 1999 .

3 S.Komatu,S.Uegusa; Reduction evolution of the sciencetechnology system 2000 .

${ }^{4}$ Statistics Bureau \& Statistics Center ; A residence and land statistics investigation 2000 .

Presented at '01 SAS Intelligent Symposium 